\title{
Effect of the Extract of Ricinus communis $L$. on the Osmotic Fragility, Labeling of Red Blood Cells with Technetium-99m and Morphology of the Cells
}

\author{
Kristiana Cerqueira Mousinho ${ }^{1,2}$, Marília Bezerra Libório Correia ${ }^{1,3}$, Jailson Oliveira da \\ Silva ${ }^{1}$, Simey de Souza Leão Pereira Magnata ${ }^{1,3}$, Ivone Antônia de Souza ${ }^{4}$ and Maria \\ Teresa Jansem de Almeida Catanho ${ }^{1}$ \\ ${ }^{I}$ Departamento de Biofísica e Radiobiologia; Universidade Federal de Pernambuco; Av. Prof. Morais Rego,S/N; \\ Cidade Universitária; kiu.mousinho@bol.com.br; Recife - PE - Brasil. ${ }^{2}$ Departamento de Farmácia, Universidade \\ Federal de Pernambuco; Recife - PE - Brasil. ${ }^{3}$ Departamento de Energia Nuclear, Universidade Federal de \\ Pernambuco;Recife - PE - Brasil. ${ }^{4}$ Departamentode Antibióticos, Universidade Federal Pernambuco; Recife - PE - \\ Brasil
}

\begin{abstract}
The aim of this study was to evaluate the influence of the proteic extract of $R$. communis on the cell physiology by the osmotic fragility, labeling of the blood elements with the $99 m T c$ and cell morphology. To evaluate the osmotic fragility, the blood samples of the Wistar rats were incubated with the concentrations of R. communis and with the solutions of $\mathrm{NaCl}(0.4 ; 0.7 ; 0.9 \%)$. In the labeling of the blood elements procedure, the rat blood was treated with a solution of Tc-99m and TCA at 5\%, determining the rate of radioactivity (\%ATI) in the plasma $(P)$ and in the red blood cells $(\mathrm{RBC})$. The soluble and insoluble fractions of the plasma were also evaluated. The cells morphology submitted to the extract was evaluated by the optical microscopy (x40). The results indicated that the rate of the hemolysis increased in the presence of $0.125 \mathrm{mg} / \mathrm{mL}$ of the extract. There was a decay of $49.69 \%$ in the rate of ATI in the insoluble fraction of the cells, with the morphological alterations in the red blood cells. These results suggested that the extract changed the capability of binding of the red blood cells due to the stannous ion oxidation, modifying the cells structure.
\end{abstract}

Key words: Ricinus communis L., labeling of red blood cells, osmotic fragility, Technetium-99m, morphology of cells

\section{INTRODUCTION}

The use of natural products has increased in the recent years (Olsnes et al., 2001; Souza, 2005). Ricinus communis $L$. is an Euforbiaceae with large palm leaves. From its typical fruits the "ricin oil" is extracted which is used as the lubricant in the industry, as laxative, purgative and in the treatment of the terminal cancer in the folk medicine (Corrêa, 1984; Feijão, 1963; Olsnes, 2004; Souza et al., 1992). It's a highly toxic plant for the animals (Koga et al., 1979) and has a proved antitumor action (Feijão, 1963; Fodstad et al., 1979; Souza et al., 1992; Zhou et al., 2003).

\footnotetext{
* Author for correspondence
} 
The osmotic fragility evaluates yhe qualitatively influence of the extract on the red blood cells $(\mathrm{RBC})$. The labeling of the red blood cells with the technetium-99m ( (99m TC-RBC) has been usually studied. The technetium has been the most utilized radionuclide in the nuclear medicine because of its acceptable physical characteristics: six hours of plasma half-life and despicable environment impact (Saha, 1998). It is used in the study of the natural or synthetic drugs influence in the labeling of the RBC and the plasma proteins (Braga et al., 2000; Dantas et al., 2005; Holanda, 2004; Oliveira et al., 2000; Souza et al., 2005). The aim of this study was to evaluate the capability of different concentrations of the non-oily fraction of $R$. communis to modify the physiological properties (osmotic fragility), labeling of the RBC and plasma proteins with the technetium-99m and morphology of the cells.

\section{MATERIALS AND METHODS}

\section{Plant Materials}

$R$. communis $L$. was collected from the district of Pau Amarelo in the town of Paulista-Pernambuco and identified by Dr. Marlene Barbosa. The species are located in the Geraldo Mariz herbarium, number 52116, of the Federal University of Pernambuco-Brazil.

\section{Extract preparation}

The seeds were selected, dried at $37^{\circ} \mathrm{C}$ and triturated. In the first step, the hydroalcoholic extract was prepared from seeds by extracting in EtOH: $\mathrm{H}_{2} \mathrm{O}(8: 2, \mathrm{v} / \mathrm{v})$ for $72 \mathrm{~h}$ at room temperature, it was filtered and dried. Then, the oil extraction was prepared by acetone submission and drying under vacuum, obtaining the proteic fraction. The proteic fraction was employed in the follow procedures by previous dilution with Tween 80 and salt solution $0.9 \%$.

\section{Osmotic Fragility}

The venous blood samples $(0.5 \mathrm{~mL})$ in the presence of heparin were incubated with $0.5 \mathrm{~mL}$ of the extract of $R$. communis in different concentrations $(0.125 \mathrm{mg} / \mathrm{mL}, 0.0625 \mathrm{mg} / \mathrm{mL}, 0.0312 \mathrm{mg} / \mathrm{mL})$ for one hour at room temperature. The control group was incubated with $0.5 \mathrm{ml}$ salt solution $0.9 \%$. After the incubation, the samples were washed three times with $\mathrm{NaCl}(0.9 \%)$ to remove the excess of the extract. The blood cells were resuspended in $\mathrm{NaCl}(0.9 \%)$. The RBC osmotic fragility was evaluated by the Dacie method (1984), with some modifications. The samples $(50 \mu \mathrm{L})$ treated with $R$. Communis were submitted to $5 \mathrm{~mL}$ of different $\mathrm{NaCl}$ concentrations $(0.4 ; 0.7 ; 0.9 \%)$ for $1 \mathrm{~h}$ at room temperature. These tubes were centrifuged in the clinical centrifuge (EXCEL SA2, Fanem Ltda) at $2000 \mathrm{rpm}$ for 5 minutes. The sobrenadants were isolated and the optical density (OD) was determinated in the spectrophotometer (model UV-Vis 634-5 Fab.: Varian) $545 \mathrm{~nm}$. After this, the osmotic fragility was determinated as the function of the hemolysis percent

\section{Labeling of the blood elements}

The samples of $0.5 \mathrm{~mL}$ of Wistar rats blood, with heparin were incubated at room temperature for $1 \mathrm{~h}$ with $100 \mu \mathrm{L}$ of $R s$ communis, at predetermined concentrations $(100 \%-0.0625 \mathrm{mg} / \mathrm{mL}, 50 \%-0.0312$ $\mathrm{mg} / \mathrm{mL}, \quad 25 \%-0.0156 \mathrm{mg} / \mathrm{mL}, \quad 12.5 \%-0.0078$ $\mathrm{mg} / \mathrm{mL}, 6.25 \%-0.0039 \mathrm{mg} / \mathrm{mL}$ ), and the control group containing salt solution $(0.9 \%)$. Then $0.5 \mathrm{ml}$ of stannous chlorite $\left(\mathrm{SnCl}_{2}-1.2 \mu \mathrm{L} / \mathrm{mL}\right)$ was added at room temperature. After $1 \mathrm{~h} 0.1 \mathrm{~mL}$ of sodium pertechnetate $\left({ }^{99 m} \mathrm{NaTcO}_{4}-3.7 \mathrm{MBq}\right)$ was added and incubated for 10 minutes. The samples were centrifuged at $1500 \mathrm{rpm}$ for 5 minutes, in order to separate the fractions containg the plasma $(\mathrm{P})$ and red blood cells (RBC), respectively. Aliquots of 20 $\mu \mathrm{L}$ of the plasma and cells were used for the counting of radioactivity, calculating the percentage (\%ATI). Aliquots of $20 \mu \mathrm{L}$ of $\mathrm{P}$ and RBC were precipitated with $1 \mathrm{~mL}$ of trichloroacetic acid (TCA 5\%) and centrifuged (1500 rpm; $5 \mathrm{~min}$.) to isolate the soluble and insoluble fractions of the plasma (SF-P; IF-P) and cell (SF-RBC; IF-RBC). In both the experiments the radioactivity was counted in the gamma counter (model DPC-Gambyt CR. Série: 953/1122) and calculated as \%ATI.

\section{Morphology of the cells}

Sample blood of Wistar rats were submitted to $R$. communis extract at 0.0625 and $0.125 \mathrm{mg} / \mathrm{mL}$ concentrations for $1 \mathrm{~h}$. In the control group the blood was submitted to salt solution at $0.9 \%$ under same conditions. Blood smears in microscope shades were prepared, dried, fixed and staining. The morphology of the red blood cells was evaluated under optical microscope $(\mathrm{x} 40)$. 


\section{Statistical Analysis}

Each assay was made three times. The results were analyzed by the T-student test, comparing control to experimental groups. The differences were considered significant in the values with $\mathrm{p} \leq 0.05$. The tests were performed in Excel Office 2003.

\section{RESULTS}

Osmotic Fragility in mice red blood cells with Ricinus communis.

Fig. 1 shows the hemolysis percentage on the RBC samples treated with different $R$. communis concentrations. The $0.062 \mathrm{mg} / \mathrm{mL}$ and 0.031 $\mathrm{mg} / \mathrm{mL}$ extract concentrations had the same behavior on the osmotic fragility than the control group at 0.0 and $0.4 \% \mathrm{NaCl}$; these concentrations at 0.7 and $0.9 \% \mathrm{NaCl}$ showed $\% \mathrm{H}$ bigger than control group. As for control group as well for these concentrations a significant decrease $(\mathrm{p}<0.05)$ in the hemolysis rate $(\% \mathrm{H})$ is observed at $0.4 ; 0.7$ and $0.9 \% \mathrm{NaCl}$ in comparison to no $\mathrm{NaCl}$. On the other hand, the $0.125 \mathrm{mg} / \mathrm{mL}$ extract presented a different hemolysis profile: a decrease in $\% \mathrm{H}(50 \%)$ can be observed in comparison with the others extract concentrations without $\mathrm{NaCl}$, while at $0.4 ; 0.7$ and $0.9 \% \mathrm{NaCl}$ there was trends to stabilize $\% \mathrm{H}$ which became bigger than others concentrations, including the control group. The $0.125 \mathrm{mg} / \mathrm{mL}$ extract supported practically the same $\% \mathrm{H}$ at any $\mathrm{NaCl}$ solution.

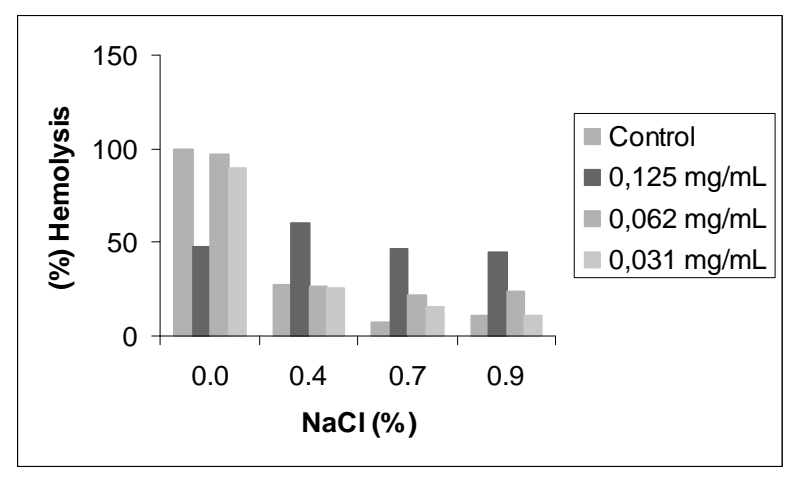

Figure 1 - The diagram of osmotic fragility cells (RBC) after treatment with Ricinus communis $L$. The mean values are representative of tree similar experiments.

\section{Labeling of Red Blood Cells with Technetium-} 99m.

Fig. 2 shows the distribution of the radioactivity in the red blood cells $(\mathrm{RBC})$ and plasma $(\mathrm{P})$, treated with different concentrations of $R$. communis. Results indicated that there was a significant decrease $(p<0.05)$ of the radioactivity in $25 \%$
(84.77\%), 50\% (64.87\%), 100\% (58.55\%) of the extract in the RBC while it had a significant increase in the binding with the plasma in the same fraction with $15.23 ; 35.13$ and $41.45 \%$ respectively. Fig. 3 shows the distribution of the radioactivity in the insoluble and soluble fractions of the red blood cells (IF-RBC; SF-RBC).

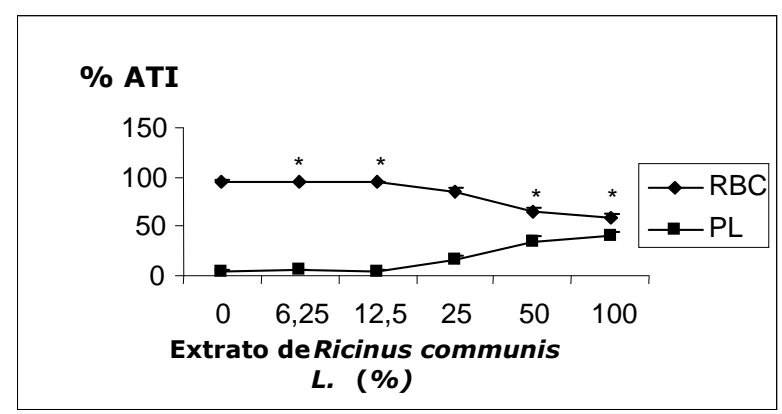

Figure 2 - Effects of Ricinus communis extract in fixation of Tc-99m on the plasma and red blood cells in water. The results are averages \pm standard deviations with Test-T, $* \mathrm{p}<0.05$. 


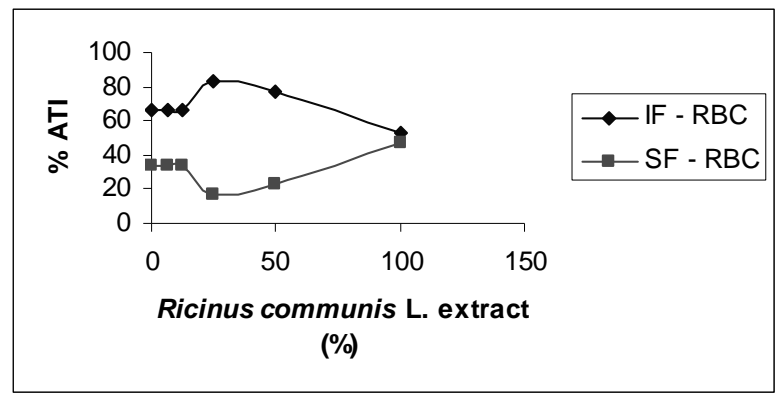

Figure 3 - Effects of Ricinus communis extract in fixation of Tc-99m on insoluble and soluble RBC fraction. The results are averages \pm standard deviations with Test-T, $* \mathrm{p}<0.05$.

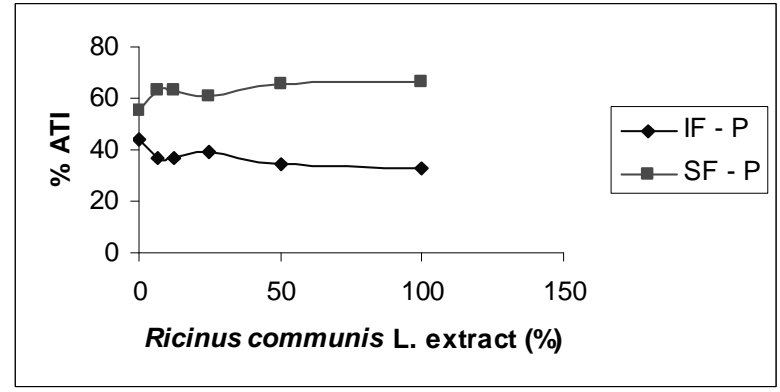

Figure 4 - Effects of Ricinus communis extract in fixation of Tc-99m on insoluble and solube P fraction. The results are averages \pm standard deviations with Test-T, ${ }^{*} \mathrm{p}<0.05$.

Results indicated that there was a significant alteration $(\mathrm{p}<0.05)$. In the doses from $0 \%$ to $25 \%$, the uptake of Tc-99m increased in IF-RBC but from $25 \%$ to $100 \%$ the $\%$ ATI decreased, thus the radioactivity ratio was the same for both IF-RBC and SF-RBC at $100 \%$. Fig. 4 shows the insoluble and soluble fractions of the plasma (IF-P; SF-P) in the blood treated with different concentrations of the solution of $R$. communis and TCA at $5 \%$. In this case, the \% ATI remained unchanged through extract concentrations, with just some variations from $0 \%$ to $25 \%$.

\section{The morphology of the red blood cells}

Fig. 5 shows the histological preparation of RBC (control group - not treated) in contact with a physiological solution $(0.9 \%)$. The cells were discoid, anucleate and with normal aspect. Fig. 6 shows the RBC treated with $R$. communis $(0.062$ $\mathrm{mg} / \mathrm{mL}$ ). Little morphological alterations in the cells, including little hemolysis, were observed in comparison with the control group. Fig. 7 shows the treatment realized in the concentration of 0.125 $\mathrm{mg} / \mathrm{mL}$ of $R$. communis, presenting important alterations in the cells morphology with the break of cells membrane, fragmentation, hemolysis and hemoagglutination.

\section{DISCUSSION}

The cell membrane integrity depends on environment tonicity and substances which can interfere on membrane matrix. Several substances can change this equilibrium and is especially interesting the knowledge about those whose employment presents medical applications. This work studied the in vitro effects of $R$. communis on RBC cell membrane by osmotic fragility, morphology and ${ }^{99 \mathrm{~m}} \mathrm{Tc}$ labeling capability. Osmotic fragility results indicated that the $R$. communis at $0.125 \mathrm{mg} / \mathrm{mL}$ presented a particular behavior, there was an increase in $\% \mathrm{H}$ in the concentration at $0.4 ; 0.7$ and $0.9 \% \mathrm{NaCl}$ in 
comparison with each control group respectively, although without $\mathrm{NaCl}$ this concentration liked have protective effect on the cell membrane. Any way, the $0.125 \mathrm{mg} / \mathrm{mL}$ extract promoted similar
$\% \mathrm{H}$ independent of $\mathrm{NaCl}$ presence. The microscopical analyze of RBC under the 0.125 $\mathrm{mg} / \mathrm{mL}$ concentration showed hard alteration on the membrane.

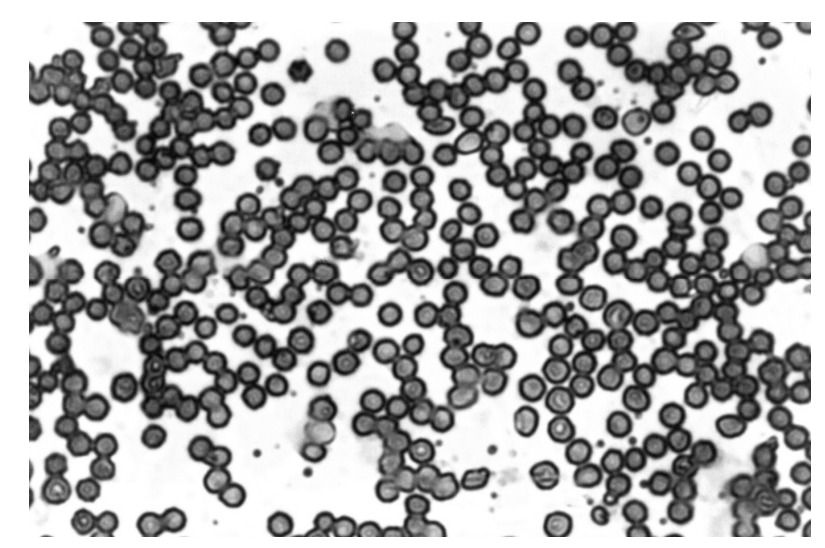

Figure 5 - Control group cells -. Blood smears were prepared, dried, fixed and staining. After that, the morphology of the red blood cells as evaluated under optical microscope $(\mathrm{x} 40)$.

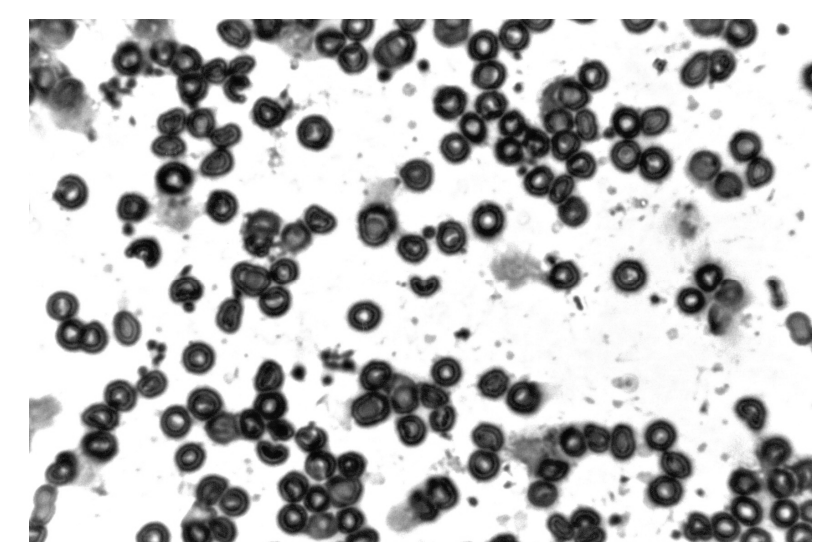

Figure 6 - In the presence of the extract of $R$. communis $L .(0.062 \mathrm{mg} / \mathrm{mL})$. Blood smears in micorospcopes shades, the RBC morphology was evaluated under optical microscope (x40). 


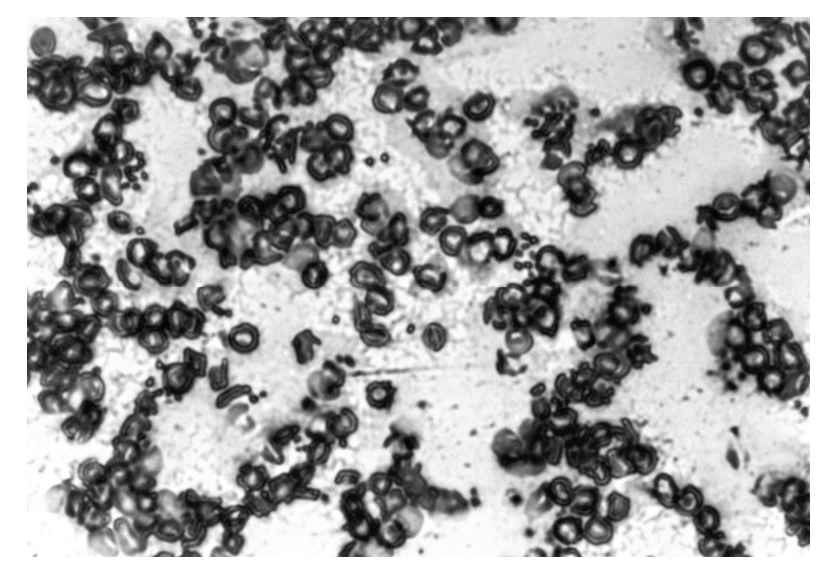

Figure 7 - In the presence of the extract of Ricinus communis L. $(0.125 \mathrm{mg} / \mathrm{mL})$. Blood smears in micorospcopes shades, the RBC morphology was evaluated under optical microscope (x40).

Both results suggested that the damage on membrane exists and is unchangeable, no matter environmental $\mathrm{NaCl}$ concentrations. It was proved $R$. communis $L$. to be an extremely toxic plant to animals and cells in growth in vitro (Koga et al., 1979; Zhou et al., 2003). According to osmotic fragility results, the $R$. communis from 0.062 $\mathrm{mg} / \mathrm{mL}$ does not cause serious morphological alterations. Since the aim of RBC labeling is to evaluate how much the vegetable extract can alter the ${ }^{99 \mathrm{~m}} \mathrm{Tc}$ biding on plasma and erythrocytes, thus is not of interest apply an extract which lyses the cell. Because it the $R$. communis $0.062 \mathrm{mg} / \mathrm{mL}$ was used as $100 \%$ in the RBC labeling and then it was used to prepare the dilutions. There was no alteration in the RBC labeling from $6.25 \%$ to $25 \%$ extract concentrations when compared to the control group. However, a \%ATI decay of $49.69 \%$ at $100 \%$ concentration was observed (Fig. 2) while the plasma radioactivity increased, reflecting morphological alterations in RBC at this concentration. Then, both fractions, cellular and plasmatic, were observed separately using TCA as precipitating agent in order to distinguish the proteic structures in each fraction. On the hand, evaluating only the cellular fraction (RBC labeling - Fig.3) the behavior was not unidirectional, the radioactivity on the IF-RBC rose at $25 \%$ extract, from this point until $100 \%$ extract the IF-RBC radioactivity decayed and ${ }^{99 \mathrm{~m}} \mathrm{Tc}$ presence increased on the SF-RBC. From 25 until 100\% extract is observed a radiomodifier action with $30 \%$ magnitude dislocating the ${ }^{99 \mathrm{~m}} \mathrm{Tc}$ to no proteic fraction of erythrocytes. On the other hand, the extract did not change the labeling between IF-P and SF-P (Fig. 4), probably the $R$ communis does not alter biding with plasmatic proteins. Early studies show the action of synthetic and natural drugs, Thuya occidentallis, Tabacco, Cauliflower, Maytenus ilicifolia, Paullinea cupana and Coffee beans that interfere in the RBC labeling with ${ }^{99 \mathrm{~m}} \mathrm{TC}$ (Oliveira et al., 1997; Vidal et al., 1998; Lima et al., 2002; Oliveira et al., 2000; Oliveira et al., 2002; Oliveira et al., 2003). The mechanism for the fixation of ${ }^{99 \mathrm{~m}} \mathrm{TC}$ in the RBC consists in the binding of the radioactive element in the hemoglobin by the $\beta$ channel found in the cells membrane (Bernardo-Filho et al., 2005), but the ${ }^{99 \mathrm{~m}} \mathrm{Tc}$ labeling also depends on reduction by stannous ion. Others studies show that the toxin ricin promotes an agglutination of the erythrocytes and precipitation of the serium proteins (Olsnes, 2004). This work found that the proteic fraction of $R$. communis hydroalcoholic extract may alter the labeling of RBC and IF-RBC decreasing the fixation of the radioactivity in the blood cells. The results of this study suggest that the proteic extract of Ricinus communis promotes toxic effects and may change the binding capability of the RBC due to either interfering oxidation capability stannous ion or direct inhibition (chelating action) referring to the ions competition for the binding sites of the pertechnetate ion or modifying the cells membrane structure.

\section{ACKNOWLEDGMENTS}

To Vitor Ferreira and Mariane for the English review and for the manuscript layout. 


\section{RESUMO}

Produtos naturais são usados freqüentemente por muitas pessoas no tratamento do câncer. O Ricinus communis L é uma Euforbiaceae que apresenta propriedades laxativas, purgativas e antitumorais. O objetivo deste trabalho é estudar a influência da fração protéica do extrato hidroalcoólico de $R$. communis $L$. na fisiologia celular através da fragilidade osmótica, da marcação de elementos sanguíneo com ${ }^{99 \mathrm{~m}} \mathrm{Tc}$ e da morfologia celular. Para avaliar a fragilidade osmótica, amostras de sangue de ratos Wistar foram incubadas com concentrações de $R$. communis e com soluções de $\mathrm{NaCl}(0,4 ; 0,7 ; 0,9 \%)$. No procedimento de marcação de elementos sanguíneos, as amostras de sangue foram tratadas com solução de Tc-99m e TCA à 5\%, determinando o percentual de radioatividade (\%ATI) no plasma $(\mathrm{P})$ e nas células vermelhas $(\mathrm{RBC})$; as frações solúvel e insolúvel do plasma também foram avaliadas. A morfologia das células submetidas ao extrato foi avaliada por microscopia óptica (x40). Os resultados indicam que o extrato na concentração de $0,125 \mathrm{mg} / \mathrm{mL}$ provoca hemólise de $49,69 \%$, no \% ATI na fração insolúvel das células, ocorrendo alterações morfológicas das células sangüíneas. Esses resultados sugerem que o extrato radiomodifica a ligação do ${ }^{99 \mathrm{~m}} \mathrm{Tc}$ às células vermelhas. Isto pode ser devido à oxidação do íon estanoso, a um processo de competição com os sítios de ligação do ${ }^{99 \mathrm{~m}} \mathrm{Tc}$ ou por modificação das estruturas da membrana.

\section{REFERENCES}

Bernardo-Filho, M.; Santos-Filho, S.D.; Moura, E.G.; Maiworm, A.I.; Orlando, M.M.C.; Penas, M.E.; Cardoso, V.N.; Bernardo, L.C. and Brito, L.C. (2005), Drug Interation with Radiopharmaceuticals: a Review. Braz Arch of Biol and Tech, 48, 13-27.

Braga, A.C.S.; Oliveira, M.B.N.; Feliciano, G.D.; Reiniger, I.W.; Oliveira, J.F.; Silva, C.R. and Bernardo-Filho, M. (2000), The effect Of Drugs on the Labeling of Blood Elements with Technetium99m. Curr Pharm Design, 6, 1179-1191.

Correa, M.P. (1984), Dicionário das Plantas Úteis do Brasil e das Exóticas Cultivadas. Ed. Imprensa Nacional. Rio de Janeiro, 63.
Dacie, J.V. and Lewis, S.M. (1984), In: Pratical Haematology. Investigation of the Hereditary haemolytic anemias. $6^{\mathrm{a}}$ ed. Goudon Smith, Churchie, Livingstone, New York.

Dantas, A.L.A.; Valente, L.A.S.; Feliciano, G. and Bernardo-Filho, M. (2005), In Vitro Study of Vellozia pusilla Pohl (Velloziaceae), a Brasilian Plant Species: Antitumoral Activity and Labeling of Blood Elements. Braz Arch of Biol and Tech, 48, 57-61.

Feijão, R. D’O. (1963), Rícino. Elucidário Fitológico, ed. Instituto Botânico de Lisboa, 3, 111-112.

Fodstad, O.; Johannessen, J.V.; Schjerven, L. and Pihl, A. (1979), Toxicity of Abrin and Ricin in Mice and Dogs. Jour of Tox and Env Pheal, 5, 1073-1084.

Fonseca, A.S.; Frydman, J.N.G.; Rocha, V.C. and Bernardo-Filho, M. (2005), Acetylsalicylic Acid and Labeling of Blood Constituents with Technetium9mm. Braz Arch of Biol and Tech, 48, 163-168.

Holanda, C.M.C.X. (2004), Avaliação da Influência do Glucantime ${ }^{\circledR}$ na Marcação de Radiofármacos com Tecnécio-99m em Ratos Wistar, utilizando Modelos in vivo e in vitro. Tese de Doutorado, Universidade Federal do Rio Grande do Norte, Natal, Brasil.

Koga, M.; Ohtsu, M. and Funatsu, G. (1979), Cytotoxic, cell agglutinating, and Syncytium forming effect of purified lectins from Ricinus communis on cultured Cells. Gann, 70, 585-591.

Lima, E.A.; Dire, G.; Mattos, D.M.; Freitas, R.S.; Gomes, M.L.; De-Oliveira, M.B.; Faria, M.V.; Jales, R.L. and Bernardo-Filho, M. (2002), Effect of na extract of cauliflower (leaf) on the labeling of blood elements with technetium-99m and the survival of Escherichia coli AB1157 submitted to the treatment with stannous chloride. Food Chem Toxicol, 40, 919923.

Oliveira, J.F.; Braga, A.C.S.; Ávila, A.S.; Fonseca, L.M.B.; Gutfilen, B. and Bernardo-Filho, M. (1997), Effect of Thuya occidentalis on the Labeling of Red Blood Cells and Plasma proteins with Technetium-99m. Yale Journal of Biology and Medicine., 69, 489-494.

Oliveira, J.F.; Braga, A.C.S.; Oliveira, M.B.N.; Ávila, A.S.; Caldeira-de-Araújo, A.; Cardoso, V.N.; Bezerra, R.J.A.C. and Bernardo-Filho, M. (2000), Assessment of the Effect of Maytenus ilicifolia (Espinheira Santa) extract on the Labeling of Red Blood Cells and Plasma proteins with Technetium99m. Jour of Ethno, 72, 179-184.

Oliveira, J.F.; Ávila, A.A.; Braga, A.C.S.; Oliveira, M.B.N.; Boasquevisque, E.M.; Jales, R.J.; Cardoso, V.N. and Bernardo-Filho, M. (2002), Effect of Extract of Medicinal Plants on the Labeling of Blood elements with Technetium-99m and on the Morphology of Red Blood Cells: I- a study with Paullinia cupana. Fitoterapia., 73, 305-312. 
Oliveira, J.F.; Santos-Filho, S.D.; Catanho, M. T. S. A.; Srivastava, S.C.; Lima-Filho, G.L. and BernardoFilho, M. (2003), Effect of Extract of Medicinal Plants on the Labelling of Blood Elements with Technetium-99m and on the Morphology of Red Blood Cells (RBC): Toxicological Actions of Roast Coffee beans (Coffea Arabica). Indian Jour of Nuc Med, 18, 52-56.

Olsnes, S. and Kozlov, J.V. (2001), Ricin. Toxicon, 39, 1723-1728.

Olsnes, S. (2004), The History of Ricin, Abrin and Related Toxins. Toxicon, 44, 361-370.

Saha, G. (1998), Fundamentals of Nuclear Pharmacy. $4^{\text {th }}$ ed. New York: Springer, 80-87.

Souza, G.M.L.; Carvalho, E.B. and Catanho, M.T.J.A. (2005), Interaction of the Product Mulher Ativa ${ }^{\circledR}$ on the Labeling of Red Blood Cells and Plasma Proteins with Technetium-99m. Jour of Food Tech, 3, 417422.
Souza, I.A.; Santana, C.F.; Martins, D.G.; Santos, E.R. and Lins, L.J.P. (1992), Novas observações sobre Propriedades Antineoplásicas da Fracção não-Oleosa da semente do Ricinus communis, cultivado no Estado de Pernambuco e sua Associação com a Radiação Ionisante do $\mathrm{Co}^{60}$. Ver Port de Farm, XLIV, 139-143.

Vidal, M.V.; Gutfilen, B.; Fonseca, L.M.B. and Bernardo-Filho, M. (1998), Influence of Tabaco on the Labeling of Red Blood Cells and Plasma Proteins with Technetium-99m. Jour Exp Clin Cancer Res, 17, 41-45.

Zhou, P. and Zhan, J. (2003), A Simplified Method to Evaluate the Acute Toxicity of Ricin and Ricinus Agglutinin. Toxicology, 186, 119-123.

Received: February 03, 2006; Revised: July 26, 2007; Accepted: May 20, 2008. 